\title{
Governing Health Care Through Free Choice: Neoliberal Reforms in Denmark and the United States
}

\author{
Lars Thorup Larsen \& Deborah Stone
}

Online repository version (postprint):

This article is now published in the Journal of Health Politics, Policy and Law

http://jhppl.dukejournals.org/content/40/5/941

For citing, please use this reference:

Lars Thorup Larsen \& Deborah Stone (2015): "Governing Health Care through Free Choice: Neoliberal Reforms in Denmark and the United States", Journal of Health Politics, Policy and Law 40(5): 941-70.

\begin{abstract}
We compare free choice reforms in Denmark and the U.S in order to understand what ideas and political forces could generate such similar policy reforms in radically different political contexts. We analyze the two cases using our own interpretation of neoliberalism as having "two faces." The first face seeks to expand private markets and shrink the public sector; the second face seeks to strengthen the public sector's capacity to govern through incentives and competition.

First, we show why these two most-different cases offer a useful comparison to understand similar policy tools. Second, we develop our theoretical framework of the two faces of neoliberalism. Third, we examine Denmark's introduction of a free choice of hospitals in 2002, a policy that for the first time allowed some patients to receive care in a private hospital paid for by the public system. Fourth, we examine the introduction of free choice among private managed care plans into the U.S. Medicare program in 1997. We show how policymakers in both countries used neoliberal reform as a mechanism to make their public health care sectors governable. In part five, based on our analysis, we draw five lessons about neoliberal policy reforms.
\end{abstract}




\section{Governing Health Care Through Free Choice: Neoliberal Reforms in Denmark and the United States}

\section{Introduction}

Since about 1980, health reforms in all welfare states have increasingly been designed to restructure health policy around neoliberal ideas. Three elements characterize neoliberal reforms: first, transferring public health insurance and public delivery systems to private, for-profit companies; second, introducing market competition where formerly there had been public sector dominance or monopoly; and third, enabling citizens to choose among multiple insurance plans and/or medical service providers.

As health policy scholars in Denmark and the U.S., we were struck by the similarity of neoliberal reforms in two welfare states with dramatically different political cultures, one strongly social-democratic, the other strongly libertarian. We decided to compare the evolution and implementation of consumer freedom-of-choice reforms to understand what ideas and political forces could lead to such similar policy reforms in such different political contexts. Our hunch, inspired by Michel Foucault, was that governments in both countries somehow gained strength from policy tools that are apparently meant to weaken the state.

In our collaboration, we went back and forth between empirical analysis of the two cases and theoretical literature on neoliberalism. Eventually we evolved an interpretation of neoliberalism as having two faces (with obvious homage to Bachrach and Baratz' classic, The Two Faces of Power). The first face entails promotion of private markets and consumer choice in formerly public sectors, programs and resources, and may be understood as a retrenchment of the state. The second face entails a specific mode of governing the public sector through incentives and competition, and may be understood as an expansion of the state. To understand the second face and inquire how it actually works, we believe one must study it at the policy level because only there are the governing mechanisms visible. Indeed, as we looked at Danish and U.S. reforms through this lens, we took a special interest in whether or not the reforms were able to enhance governability in practice, for instance on factors such as cost control and the ability to meet patients' demands.

This article has five parts. First, we provide background on Denmark and the United States to show why these two most-different cases offer a useful comparison to understand similar policy tools. Second, we develop our theoretical framework of the two faces. Then in parts three and four, we analyze two specific freedom-of-choice reforms using this theoretical framework. We examine Denmark's introduction of a free choice of hospitals in 2002, a policy that for the first time allowed some patients to receive care either in a public hospital outside their local area or in a private hospital. In the fourth section, we examine the 1997 introduction of free choice among private managed care plans into the U.S. Medicare program, a public system originally somewhat comparable to the social insurance systems of Europe. We show how policymakers in both countries used neoliberal reform as a mechanism to make their public health care sectors governable. In part five, based on our analysis, we draw five lessons about neoliberal policy reforms.

\section{Why Compare Denmark and the United States?}

Health policy poses a bigger challenge to neoliberal theorists and politicians than economic policy, transportation, or education policy. The very formation of public health insurance systems was largely motivated by the failure of private markets to provide adequate insurance. Re-introducing private markets into these public systems was thus a hard sell. Nowhere was health policy the first area to be neoliberalized, and in several countries, for instance Britain under Thatcher or Denmark, health policy constituted a 
holdout against the trend towards privatization in other areas of social policy or public infrastructure.

The Danish and U.S. health care systems could not be more different. Denmark has a universal public health insurance scheme with publicly financed hospitals, and until recently, no private health insurance or hospitals to speak of. ${ }^{1}$ The system is financed primarily by payroll taxes, like the U.S. Social Security system. Danish citizens and immigrants must register for a national identity card in the town where they live. They choose a primary care doctor whose name appears on their card, and who serves as their gatekeeper to all other medical services. When they need specialist or hospital services, they must (until 2002) get their treatment at the local public hospital in their town or neighborhood, much as American children are assigned to a public school in their neighborhood (until vouchers, bussing and other programs altered that system). The United States has a fragmented system of mostly private, commercial health insurance plans with significant public insurance for the elderly, disabled, poor and veterans, yet still leaving close to a fifth of the population without insurance. Private, for-profit hospitals and clinics form an important part of the medical supply, and before the rise of managed care, patients could generally seek care at any hospital they wished (and could afford).

Besides this most obvious difference, though, there is striking variation in political culture and ideology that is essential to our claim about the two faces of neoliberalism. Denmark's national health insurance and its system of public hospitals have been virtually unanimously supported by one of the most egalitarian political cultures in the world. The health insurance system and public hospitals were a stronghold of welfare state power and legitimacy. Although the institutional configuration of national health insurance developed in several steps over the $20^{\text {th }}$ century, the core ideal that both rich and poor should have "free and equal access" to treatment goes back to the early $19^{\text {th }}$ century (Petersen \& Blomquist 1996: 185). A 1971 reform replaced the patchwork of public and not-for-profit private insurance plans with the current universal public health insurance financed by general taxes and administered by five regions (formerly by 15 counties until 2007). Up until the turn of the century, there were no significant ideological challenges to the public system nor was there any public or even elite clamor for privatizing the public health insurance system. Instead, health policy debates focused on practical problems like waiting time, which opened a back door to a series of neoliberal reforms.

In the U.S., by contrast, contentious debate embroiled every effort to establish public health insurance programs (Quadagno 2005). Advocates of social responsibility and public insurance continually square off against advocates of individual responsibility, commercial insurance and competitive free markets. Medicare, the major single-payer, taxpayer-financed social insurance program, emerged precariously from a sharply divided Congress and a sharply divided political culture-divisions that persist to this day and that have allowed conservatives to move the original Medicare program towards the private insurance model each time they gain ascendency in national government (Oberlander 2003a, 2003b).

Thus, the two cases offer a superb comparison to test our argument that neoliberalism must be seen as an expansive governing technology as well as an expansive privatizing strategy. If neoliberal policy reform exhibits similar processes in one case where the public health system is dominant and highly legitimate and in another where the public health system has always been weak and contested, there is a strong argument for having understood something basic about neoliberal politics.

\footnotetext{
${ }^{1}$ Currently, the public share of total health costs is around $85 \%$ while the remaining part consists of private co-payments for dental care, pharmaceuticals and physical therapy (OECD 2011).
} 


\section{Theoretical Approaches to Neoliberalism}

Scholars have treated neoliberalism as normative political theory, as an international political movement, and as a set of policy tools. As normative theory, neoliberals claim that if certain free-market reforms are followed, economic productivity and innovation will increase and therefore social welfare will also improve (Hayek 1960; Friedman 1962; Buchanan 1986; Niskanen 1971; Mueller 2003). Neoliberals also hold individual freedom as the highest political value, and believe that freedom is a zero-sum quantity - the more power the state has, the less the individual can have (Hayek 1960; Friedman 1962; Nozick 1974). Freedom becomes redefined as the capacity to exercise discrete consumption choices, with scant attention to how poverty and powerlessness constrain those choices (Frank 2000). This understanding of freedom also rationalizes a smaller state (Hayek 1960, Friedman 1962; Rand 1957; Gilder 1984). As an international political movement, neoliberalism describes a set of reforms adopted by or imposed on many countries: free trade, low inflation monetary policy, and privatization of core parts of the public sector such as transportation, telecommunication, schools or prisons (Harvey 2005; Klein 2007; Blyth 2002). As a set of policy tools, neoliberalism prescribes certain policy reforms to reconfigure the relationship between public and private power, with the intent to strengthen the position of private market actors and individuals vis-à-vis the state (Friedman 1962; Schultze 1977; Rhodes 1994; Jessop 2002; Campbell and Pedersen 2001). These reforms include lowering taxes, deregulating business, dismantling welfare entitlements, and encouraging competitive markets as the best mode of producing goods and services.

These approaches operate on different levels and involve different actors, but they all understand the development of neoliberalism as a one-directional movement: the state contracts while the market and individual freedom expand. The activity of governing, once the defining characteristic of the state, devolves down to individuals, who, freed from government regulation and restriction, become entrepreneurs of their own lives. This is what we call the first face of neoliberalism: the replacement of government with markets in which individuals can freely choose how they want to behave. In this narrative, the state is always portrayed with decline metaphors. It diminishes, retreats, withdraws, scales back, devolves, privatizes, retrenches, rolls back, withers, or is hollowed out. Most scholarship on neoliberalism tends to follow this state decline story.

Some recent revisionist scholarship questions the dominant characterization of neoliberalism as smaller government and freer markets by documenting an increase in regulatory agencies and activities following privatization reforms (Levi-Faur (2005); Brown and Jacobs 2008; Braithwaite 2008; Cahill 2011). Often, however, these scholars isolate one policy development that diverges from the decline story and treat it as an exception that weakens but does not nullify the decline theory. For instance, Wacquant (2009) juxtaposes economic and social deregulation in the US with the expansion of its penal apparatus, thereby making penal regulation an anomaly, albeit an important one. Similarly, Braithwaite (2008) argues that growth in regulation is the exception to other kinds of state shrinkage in production and distribution of services. While we do not disagree with these studies, by naming a second face of neoliberalism and showing how it works, we insist that an expansive technology of governing is a core feature of neoliberalism, not merely an anomalous and incidental side development or a later stage of neoliberalism.

The inspiration to associate neoliberalism with governing comes from Foucault (2008) who proposed to replace ideological understandings of both liberalism and neoliberalism with a focus on their respective technologies of governing. In this view, individual freedom and private markets are not simply normative ideals, but institutions that need to be constructed first. Furthermore, Foucault adds (2008: 63-4), the construction of freedom always requires intervention against other freedoms, e.g. monopolies. Foucault distinguishes neoliberal technologies of governing substantially from classical liberalism 
even though both European (Hayek 1960) and American neoliberals (Friedman 1962; Becker 1976) themselves credit their ideas to Adam Smith and others. Rather than simply strengthening markets with laissez-faire policies, as classical liberalism does, neoliberalism generalizes the model of market competition to all spheres of society (Foucault 2008: 120-1). It is not only that business markets have to be actively constructed, but that competition becomes the main principle of governing any social sphere.

For Foucault, another essential characteristic of neoliberal governing technology is its use of the motivational structure of homo oeconomicus. Homo oeconomicus as a self-interested and profit-maximizing economic agent was already a main character in eighteenth-century liberalism, but as a subject whose interests and property could not be infringed upon by public authorities, an "intangible element with regard to the exercise of power," as Foucault says (2008: 270). The neoliberal incarnation of homo oeconomicus, on the contrary "appears precisely as someone manageable, someone who responds systematically to systematic modifications artificially introduced into the environment. Homo oeconomicus is someone who is eminently governable. From being the intangible partner of laissez-faire, homo oeconomicus now becomes the correlate of a governmentality" (Foucault, 2008: 270-1, emphases added). In other words, manipulating economic incentives becomes a vehicle for directing individual behavior, just as B.F. Skinner (1971) manipulated elements in a rat's environment to induce it to behave as the trainer wished. Whether the behavior entails a patient's demand for certain health services or a doctor's decision to prescribe certain treatment, neoliberal technology assumes that all types of behavior are amenable to manipulation through economic incentives.

The second face of neoliberalism might well be called "governing through incentives," and indeed, this is what some neoliberals advocate (Becker 1976; Schultze 1977; Thaler and Sunstein 2009). Thus, we are not claiming to have identified something new. Rather, we claim that this technology of governing is intentional within neoliberalism but generally overlooked in the first-face stories of state decline. First-face interpretations also ignore the inherent contradiction in the neoliberal claim about how markets expand individual freedom. In a market-based system, individuals exert their "free choice," but are at the same time guided by those who designed the incentives to induce more or less of a certain behavior. In other words, governing through incentives is also an exercise of power over the behavior of people supposedly free to choose (Kohn 1983; Stone 2012, chap. 12; Greenfield 2012).

In emphasizing the second face, we are not suggesting that the two faces are necessarily incompatible or mutually exclusive. They can and do operate simultaneously. For example, free choice options for patients to choose among health providers enable health authorities to control the production of health services while at the same time making it possible to contract out their delivery to the private sector. In order to understand how neoliberalism works, we believe it is essential to see it as a two-sided dynamic in which public provision of social welfare might be constrained, but in a way that installs a new governing mechanism using incentives and competition.

\section{Denmark: Extended Free Choice of Hospitals (2002)}

At first sight, the Danish health care sector is not an obvious example of the impact of neoliberalism, at least according to a first face understanding. The sector has not been haunted by dramatic cutbacks or large-scale privatization. However, a series of policy 
reforms over the past decade clearly combine elements of the two faces, i.e. promoting private actors and governing through competition and incentives.

Danish universal health insurance enjoys a high level of public support. Almost all attempts by health economists and the Liberal-Conservative government (in office 1982 1993) to introduce elements of private market or user payments in the health care sector simply failed (Petersen 1980; Mikkelsen and Steenstrup 1988). Moreover, before the reforms of the last decade, there were very few private insurers and providers to lobby for privatization. When the "extended free choice of hospitals" was introduced in 2002, it was thus not pushed by a strong private sector nor was it a response to a cost crisis. In fact, up until this time, cost control mechanisms had kept health spending stable at around $8-9 \%$ of GDP (Pallesen 1997). The reform was basically a maximum waiting time guarantee. If a patient's home hospital cannot provide treatment within two months of a referral, the patient can choose to obtain treatment from other public and private hospitals at no charge, except for possible travel costs.

The reform was thus not a result of direct business influence or an immediate cost crisis. Instead, four factors are essential in explaining this free-choice reform. First, during the 1990s and early 2000 s, leaders and media defined long waiting times for nonacute hospital care as the major health policy issue, and one that government had to address. Second, leaders explicitly hailed the reform as an instrument for governing public hospitals through economic incentives. Third, the newly elected Prime Minister Anders Fogh Rasmussen announced the free choice reform as part of a "cultural struggle" over the nature of the Danish welfare state. And finally, the reform was part of a broader ambition to expand the private sector and give it access to patients from the public system. Below, we show how each factor relates to the two faces of neoliberalism.

\section{The Waiting List as Political Problem}

Individual patients may accept long waiting for health services voluntarily, for example, if they prefer to schedule an operation at a convenient time. The political problem of waiting time, however, is something completely different. It occurs when individual patients seek access to treatment through their general practitioner, who is the gatekeeper to most specialist and hospital treatment (Pallesen and Dahl Pedersen 2008: 231). ${ }^{2}$ The GP's referral typically sends the patient to the nearest public hospital with the appropriate specialty, and if this 'home' hospital cannot provide the specified treatment within 30 days, the patient is given a later appointment date... This is how waiting time emerges in practice, but it is important to add how waiting time was also socially constructed as a problem.

Lengthening waiting time was actually a side effect of the strict (and quite successful) cost control measures during the 1980s. Solving one problem thus created another, but before the reduction of waiting time in the health care sector became a political priority, waiting time was first constructed as something the central administration could use to measure the productivity of public hospitals. Despite this administrative attempt to increase productivity and despite a nominal increase in the production of hospital services, waiting times continued to grow due to increased demand, ageing and new technology (Vrangbæk 2004: 25-7).

In the 1990s, waiting time first grabbed media and public attention and was typically referred to as "the waiting list." The complex administrative measures of waiting time stand in stark contrast to how clearly and simply the waiting list functions as a symbol

\footnotetext{
${ }^{2}$ Technically, citizens can also choose the insurance Group 2 with direct access to specialists in exchange for some disadvantages. We omit this option here, since it has not been relevant for waiting time or free choice.
} 
in public perception. It suggests a physical piece of paper lying in some bureaucrat's desk drawer, a list deciding the order in which patients are admitted. Also, the image of citizens standing in line evokes all the deprivations of Eastern European socialism, and is thus a powerful political symbol.

As early as 1991, a doctor tagged the waiting lists as "lethal" and called for more cooperation between private and public actors to remove the wait (Politiken 1991). But despite a widespread belief that private hospitals could bring down the waiting lists, the Social-Democratic government (in office 1993-2001) preferred solutions within the public sector, including increased competition between public hospitals. The key policy change in this period was the original 'free choice of hospitals' introduced in 1993, which gave patients an immediate choice among public hospitals beyond their home hospital (Vrangbæk 2004: 38). Few people used the option and the general perception still persisted among voters that the health care system was underfunded.

The liberal-conservative government elected in 2001 had promised to 'fix' the waiting time problem in the health care system by making greater use of private hospitals and clinics. One of its first health policy initiatives was the "Extended Free Choice of Hospitals" in 2002, which was sweetened by extra funding for those hospitals that could document increased production (Law L64 2002). Crucially, the reform gave patients faced with more than a two-month wait a new right to seek treatment in private hospitals in Denmark or abroad, but still paid for by the Danish taxpayers at existing DRG rates (L64, comments to the law). ${ }^{3}$ On the surface, then, this reform can be seen as exemplifying the first face of neoliberalism in that it expanded the private sector. As we'll see in the next section, however, the extended free choice also expresses the second face by introducing a new governing technology.

\section{Let the Money Follow the Patient}

Health Minister Lars Løkke Rasmussen used two arguments to support the new bill in Parliament. First, the extended free choice constituted "a new and significant right for the individual patient" (L64 written presentation). The rhetoric of individual rights certainly fits with the first face of neoliberal ideology. However, most of Løkke Rasmussen's presentation focused on another argument, namely that free choice also constituted a "...new way of governing the (public) health care sector by giving the delivery units the appropriate economic incentives (...) to shorten waiting times to an acceptable level' (L64, written presentation, emphasis added). According to the Minister, the basic method of governing health care was to "let the money follow the patient" (L64, written presentation). In a way, the money already followed the patient, as most health care financing had been based on fee-for-service principles since the late 1990s and on DRGs since 2000 (Vrangbæk 2004: 48). However, public money had mainly stayed within public hospitals. The new reform opened private hospitals' access to public money. Significantly, the principle of "letting the money follow the patient" was now put forward as a direct reversal of the waiting list. Instead of letting patients wait in line until the system has time to treat them, the free choice reform pushes health care providers to chase and compete for patients.

The ambition to put the patient center stage is somewhat ambiguous, however, because the patient still appears to be a means to an end, namely, governing public hospitals through increased competition. The second face of neoliberalism is clearly manifest in the presentation of free choice as an idea about how to govern health care,

\footnotetext{
3 The law was temporarily suspended in 2008-9 following a nurses' strike.
} 
especially the public hospital sector. Two details of the reform suggest how the goal of disciplining public providers was probably a higher priority than patient freedom of choice. First, the method of paying private hospitals entailed a severe cost to the patient's home hospital. Normally, the regional health authority receives a fixed DRG or case rate for each medical service from the central government. The regional authority then pays the individual hospital or clinic, but only the marginal cost of the service, often around $50 \%$ of the DRG rate. The rest of the rate covers education, research, administration and 24-hour acute care facilities. If a hospital 'loses' a patient by failing to meet the waiting time guarantee so that free choice kicks in, the hospital loses $100 \%$ of the DRG rate, which goes to pay for the patient's treatment somewhere else (Olesen 2010: 97). Since the public hospital still incurs the costs that the overhead on the DRG rate was supposed to cover, free choice actually works as an economic sanction on public hospitals unable to meet the deadline, and it obviously creates a strong economic incentive for hospitals to increase production.

The second reason why disciplining the public system should be considered the main policy objective is that free choice was made conditional on waiting time. Consider for a moment who actually gets to exercise free choice under this reform. The large majority of patients in the health care system - 68\% in 1995 - are acute patients who get admitted to their home hospital immediately, never have to wait, and therefore can never exercise a free choice (Vrangbæk 2004: 29). Only patients who must wait more than two months for planned treatment or specialist consultation (reduced to one month in 2007) get to choose between public and private providers. In fact, if the reform works perfectly, public hospitals should be guided by the economic incentives and increase production to meet demand within the time limit, thus making free choice moot. Only when the Minister's new governing principle does not work, does patient choice kick in. Thus, the extended free choice of hospitals is far from a complete voucher program in which all citizens get a fixed amount of money to spend on services chosen from among a variety of providers, public as well as private. This is not to suggest that patients don't benefit from the free choice reform, because after all, they do get quicker access to treatment, even if only a smaller number gets to choose between public and private in practice.

First and foremost, then, the Danish free choice reform reflects the second face of neoliberalism. It is not a retreat of the state, but a way for central government to use markets against their own regional health authorities, and to expand availability of services for citizens. This governing technology works through the economic threat of losing patients to private hospitals. Waiting times did come down after 2002, at least in part as a result of the waiting time guarantee. Significantly, though, recent estimates show that patients actually wait 53 days on average, in spite of the 30-day guarantee, either because they prefer to wait for their local hospital or are unaware of their right to choose (Jørgensen and Korsgaard 2011).

\section{A Cultural Struggle for Freedom}

The extended free choice of hospitals may look like a practical solution to a pressing problem, but it also had an ideological importance in the new government's political program. In order to get elected, the new Prime Minister, Anders Fogh Rasmussen, had to renounce his 1993 book, From Social State to Minimal State. The book was inspired by Robert Nozick (1974) and famously accused the large Danish welfare state of having created a "pathetic slave nature that penetrates the entire Danish society" (Rasmussen 1993: 7). These Libertarian ideas were foreign to most Danes and had to be shelved in the electoral platform, which instead promised Danes no cutbacks in welfare or health care. But while the new government had to forego actual retrenchment, it retained its ambition to 
break the alleged cultural hegemony of left-wing elitism in both the welfare state and Danish society.

In several key speeches and interviews, the new Prime Minister called for a bourgeois 'cultural struggle' that included free choice options in health and elderly care. Although the term 'cultural struggle' was later appropriated by the 2005 Mohammad cartoon controversy, it started as a slogan about replacing welfare monopolies with taxfinanced freedom of choice (Rasmussen 2002; Kastrup 2008). The Prime Minister clearly stated this first-face neoliberal aspiration in a 2003 interview titled 'the Golden Shopping Cart': "This is where the real struggle is. On one side the centralists who want to decide over people's everyday life, those who believe they know best and prefer standard solutions. On the other side those, who - while maintaining a common responsibility for solving problems in a modern welfare society - insist that we should have a personal freedom to choose between different public providers and between public and private providers" (Hardis \& Mortensen 2003).

By not calling for massive welfare retrenchment but still offering citizens a free choice in addition to what they were already paying for, this policy claims to offer citizens more for the same money than they get under social-democratic paternalism. This illustrates that neoliberal policies do not always lead to lower taxes and a smaller state. In countries with well-entrenched universal welfare rights, the only way for neoliberals to achieve marketization is by compensating the middle class with extra benefits and choices (Jensen 2011). Any right-wing ambition to lower public expenditures was thus temporarily put on hold, but replaced with a long-term ambition to make a liberal transformation of Danish society (Hardis 2006).

\section{Growing the Private Market}

The fourth and final motive behind the free choice reform was to strengthen the private sector. No Danish politician in their right mind would ever say they wanted to strengthen private hospitals as a goal in itself, but given the nature of the reforms, it is difficult to avoid speculation about this motive. Extended free choice was designed so that if citizens exercised their right to go to a private hospital when the public hospital could not deliver within 30 days, their choice would inevitably channel public money into private hospitals. Indeed, the 2002 reform did strengthen the private hospital sector tremendously by giving it access to patients paid for by public health insurance.

Private hospitals did not emerge in Denmark until the mid-1980s. Although the Social Democrats' attempt to ban them altogether in 1987 was unsuccessful, they continued to have a very bad public image remained, even in the right wing as well as in the medical community, because making profits on health was widely regarded as wrong (Olesen 2010: 74-5). Apart from their poor public image, private hospitals lacked the ability to make profits for lack of paying customers, and the majority of them died out within a few years of startup. The market position of private hospitals was thus very weak before the 2002 reform, which - along with a few related policy initiatives - gave private hospitals and insurers a significant boom during the 2000s. The number of private hospitals grew from five in 2002 to 178 in 2008, although each of these units was much smaller than the 49 remaining public hospitals (Ministry of Health and Domestic Affairs 2007: 27). These numbers dramatically overestimate the overall change, since these 178 private hospitals still only amounted to around $3 \%$ of public health expenditure in 2008 . It was a big change within the emerging private sector, however, since an estimated $72 \%$ of their patients were now financed by public funds (Olesen 2010: 100-1). As the owner of a private hospital said: "Before, lots of the [private hospitals] ran with deficits for years and several went 
bankrupt. But now you really have to be a terrible businessman if you can't run a private hospital with profit" (Thiemann 2007).

As mentioned earlier, when patients use their right to obtain treatment in a private hospital, the hospital is paid a general DRG rate designed to cover educational, research and acute treatment obligations that Danish private hospitals simply do not have. There are no limits to how much private providers can specialize in a few highly profitable types of surgery, such as liposuction and some orthopedic procedures. It is no surprise, then, that running private hospitals has become a very profitable business thanks to patients coming from the public system. This new business environment for private hospitals became all the more apparent after the waiting time guarantee was lowered to one month in 2007 , which increased pressure on public hospitals and boosted the population of paying patients for private hospitals.

The extended free choice of hospitals is only one of the policy decisions behind the recent upsurge of private health care in Denmark. In 2002, the government created a tax exemption for supplementary private health insurance plans paid for by employers. Because all Danes have public health insurance that covers all their care in public hospitals, private supplementary insurance finds its niche by covering treatment in private hospitals and allowing policyholders to skip the public queues for non-acute care. In 2002, a minor previous tax exemption for employer-paid alcohol rehabilitation was expanded to cover all employer-provided supplementary private health insurance policies, provided employers offer them to all employees in a workplace and with no actuarial grading or risk selection. This example of policymaking without an explicit policy choice led to a massive growth of private health insurance from covering a few percent of the labor force in 2001 to covering close to one-third in 2007 (Olesen 2009).

The government's encouragement of private hospitals erupted in controversy in 2009, when the new Prime Minister, Lars Løkke Rasmussen, was accused of systematically over-compensating private hospitals during his time as health minister (2001-2007). An official report concluded that he had personally intervened to set prices for private providers delivering services for the public system $25 \%$ higher than necessary (Rigsrevisionen 2009). The surplus income came not only from patients treated in the private sector under the free choice regulation, but also from public health authorities who purchased services directly from private providers even before the patients' free choice kicked in. The revelations of this critical report lend strength to our suggestion that some officials intended the free-choice reform to boost the private sector. After government power shifted to a socialdemocratic coalition in 2011, some of these developments of private health care were partly reversed. The tax exemption for supplementary private health insurance was removed and the 30-day treatment guarantee was changed to a 30day guarantee to receive a diagnosis after which a slightly more differentiated time limit for treatment kicks in.

In sum, we think the two "faces" of neoliberalism offer a richer political analysis of the Danish free-choice reform than the standard state-retrenchment vision. Breaking the public monopoly on hospital services not only enables the growth of a private sector, but also establishes a way to govern public hospitals through tough economic sanctions. Similarly, the expansion of individual freedom of choice creates an external 'check' on the public sector and surprisingly lets neoliberal reformers offer citizens more from the state than the Social Democratic regime. These changes come at a price, however, since the total Danish health costs have soared during the past decade. 


\section{United States: The Privatization of Medicare}

According to the standard history of Medicare, the program followed a typical neoliberal path of retreating government: Medicare began in 1965 as a social insurance program but its public character was weakened by four key privatization reforms (Oberlander 2003a). We suggest that this "first-face" interpretation tells only half the story. In fact, the federal government deliberately and explicitly used privatization and market competition as technologies to govern both public health insurance and the private health insurance market.

\section{A First-Face History of Medicare}

At the time of Medicare's passage, there was widespread agreement that the elderly were not being well-served-or even covered-by private health insurers, and that therefore, government should step in to make health insurance more available to them. The debates over what became Medicare pitted two conceptions of how government should ensure access (Oberlander 2003a). One side, primarily conservatives, Republicans, southern Democrats, organized medicine and business wanted to preserve the private market. They proposed government subsidies to the elderly to help them purchase commercial policies. The other side, primarily liberals, non-southern Democrats and labor unions, believed the private market could not and would not adequately serve the elderly, and therefore, proposed a government-run, tax-financed public insurance program. In 1965, under a Democratically controlled House, Senate, and presidency (Lyndon Johnson), the liberal conception was written into law. Although the public, socialinsurance character of Medicare gained popularity and widespread political support, the ideological battle over it never subsided. Each time Republicans gained the upper hand in national government, they tilted the program towards the conservative vision of a competitive free market, with government not only insuring the elderly itself, but also helping them to purchase private commercial insurance (Oberlander 2013).

At four key moments, the original 1965 legislation was modified to open Medicare to the private sector, each time by giving beneficiaries an element of free choice. First, in 1972, as part of a push to promote Health Maintenance Organizations (HMOs), the law was amended to allow Medicare beneficiaries to enroll in "federally qualified HMOs." However, the requirements for HMOs to qualify were so stringent that seven years later, only one was participating in Medicare (Oberlander 2003b: 1114-1115). Second, the 1982 Tax Equity and Fiscal Responsibility Act (TEFRA) loosened requirements for private insurers to serve Medicare, hoping to encourage greater participation. Enrollment in managed care plans grew slightly, but a decade later in, it remained a paltry 5 percent of Medicare beneficiaries (Oberlander 2003b: 1115).

The third and most important legislative moment came in 1997 when the Balanced Budget Act significantly widened access to the "Medicare market" for commercial insurance providers. In debates leading up to the 1997 Act, conservatives wanted to restrict Medicare to a voucher or "defined benefit," in which government would provide beneficiaries a fixed sum they could use to purchase insurance. (This is the same plan that Representative Paul Ryan has advocated since 2011.) In the end, the voucher plan lost. The traditional fee-for-service Medicare plan was preserved, but beneficiaries were now encouraged to choose among competing commercial managed care insurance plans. Even though the new managed care option, named "Medicare + Choice," utterly failed to boost enrollments in private insurance, scholars consider the 1997 Balanced Budget Act as the turning point when Medicare's, legislative framework changed from a purely public insurance program to a competitive market in which public insurance was only one option. 
The fourth privatization moment came in 2003, with the Medicare Modernization Act that introduced a prescription drug benefit. Unlike hospital care and physicians' services, for which beneficiaries can still enroll in traditional Medicare, beneficiaries can obtain prescription drug coverage only through private drug insurance plans that compete to be selected by beneficiaries (Blumenthal and Morone 2009, chap. 11).

\section{Free Choice as a Government Solution to Government Problems}

Looking at these four moments, the standard neoliberal story of how a government program was "opened up" to privatization makes sense. Yet the irony of this story-and its incompleteness - lie in the fact that insurers didn't want the elderly market. Elderly people are not a profitable clientele. They get sick, decline, die, and consume lots of medical care in the process. This actuarial reality motivated the original passage of Medicare and drives the second face of Medicare privatization: government has to work hard to induce private insurers to accept the risk of insuring Medicare beneficiaries and to bear some of the high costs of this social responsibility.

Each of the free-choice reforms passed in a political environment where cost growth was purported to be the major problem in health policy. Uncontrollable Medicare spending was a problem, but it was secondary to the chief problem Medicare was meant to address: how to provide health insurance for the elderly. As a careful re-reading of the history reveals, legislators undertook each new reform because the previous one had failed to expand private coverage of the elderly. However, the preferred conservative solution, privatization, was a drastic and unpopular change, especially versions that would have transformed Medicare completely into a private insurance program. In line with Naomi Klein's "shock doctrine" thesis (2007), conservative elites opened up political space for privatization by creating a perception of crisis in the public program so that it no longer gave people psychological security. That alleged crisis was runaway spending, soon to devour the government budget (White 2001).

President Richard Nixon was the first to use the "cost crisis" metaphor in a speech in 1969 (Hackey 2013). Also in 1969, the chair of the Senate Finance Committee declared Medicare a "runaway program," (Oberlander 2003b: 1103). In political discourse, public medical expenditures almost always came clothed in alarmist adjectives: "staggering," "spiraling," "runaway," "chaotic" "galloping" and "crippling," to name a few. By the early 1990s, health care was cast an impending "catastrophe," a system about to "collapse." In 1992, President Bill Clinton made health care costs Public Enemy Number One: "If we're not going to control health care costs, you can forget about controlling the deficit, forget about America being competitive in manufacturing, and forget about restoring our health" (Hackey, 2012 chap. 2).

It is worth noting that Milton Friedman, the intellectual father of neoliberalism, played only an indirect role in health policy debates. For him, the major problem with health care was the lack of competitive free markets among doctors. Starting in Capitalism and Freedom, which appeared three years before Medicare began, his major proposal was to eliminating medical licensure, thereby permitting anyone to sell their services as a healer (Friedman 1962). Friedman's solution never gained political traction, but his larger lesson on the paramount efficiency of free markets came to dominate debates about health insurance-despite the obvious fact that competitive insurance plans were leaving ever more Americans uninsured.

Meanwhile, policy discourse was dominated by someone unknown outside health policy circles, Alain Enthoven (Enthoven 1980; Enthoven and Kronick, 1989a; 1989 b; 1991). Like Friedman, Enthoven and his frequent co-author Richard Kronick believed that 
only competitive markets could provide an efficient health care system. However in contrast to Friedman's focus medical suppliers, they focused on the demand side. They diagnosed the cause of the cost problem as faulty incentives: "Our health care system has more incentives to spend than not to spend." The fee-for-service reimbursement system "pays providers for doing more, whether or not more is appropriate." Health insurance removes any incentive for consumers to be "cost conscious." And last, "free choice of provider insurance" - that is, insurance plans that allow policyholders to use any doctor or hospital they want-"blocks cost-consciousness on the demand side by depriving the insurer of bargaining power." In other words, if patients can choose their providers, and if their insurers have to pay their claims, insurers can't bargain with providers beforehand for better rates. With this diagnosis of the cause of high medical expenditures, Enthoven and Kronick landed on consumer choice as the solution: "We propose cost-conscious informed consumer ... choice of managed care so that plans competing to serve such purchasers will have strong incentives to give value for money" (all quotes in this paragraph from Enthoven and Kronick 1991, emphases added).

Importantly for our argument, then, neoliberal theoreticians explicitly presented consumer free choice as something government could use to fix uncontrollable cost growth in its own insurance program as well as in private, employer-based ones.

\section{How Free Choice Works as a Governing Technology}

Enthoven's concept of consumers accords perfectly with Foucault's homo economicus-a person eminently manipulable by price signals in his environment. In almost Foucauldian language, Enthoven and Kronick wrote: "Presented with an opportunity to make an economically responsible choice, people will choose value for money." Further, homo economicus'psyche can be used as a technology of governing: "the dynamic created by these individual choices will give providers strong incentives to render high quality, economical care. We believe providers will respond to these incentives" (Enthoven and Kronick 1991: 2532, emphasis added). Thus could government shape doctors' and hospitals' behavior with the technology of consumer free choice.

The illusory or at least dual nature of free choice becomes apparent when we examine the institutional forms it takes. Enthoven and Kronick acknowledged, "The market for health insurance does not naturally produce results that are fair or efficient. It is plagued by problems of biased risk selection, market segmentation, inadequate information, etc. In fact, the market for health insurance cannot work at the individual level (Enthoven and Kronick 1991: 2534, emphasis added)." Instead, large organizations such as employers or "public sponsors" (e.g. Medicare) "must act as intelligent, active, collective purchasing agents and manage a process of informed cost-conscious consumer choice of managed care plans ..." p. 2534-35 emphasis added).

Here we come to a fundamental paradox: in this so-called "consumer choice" paradigm, individual choice is now tightly constrained,,to be "managed" by "collective purchasing agents." And indeed, in each of the Medicare consumer choice reforms, the federal agency responsible for Medicare takes the role of "collective purchasing agent." It sets criteria for insurance plans to participate, certifies plans, publicizes them to Medicare beneficiaries, and even, specifies how the plans must publicize themselves to beneficiaries. (All are foreshadows of Obamacare.) Beneficiaries, then, are doubly governed: once by the financial incentives built into Medicare, and once by the collective purchasing agent and insurance plans that "inform" them how to think about the options.

Nevertheless, conservatives consistently sold the new privatized versions of Medicare with free choice rhetoric. The 1997 Balanced Budget Act packaged the new program in a brilliant rhetorical flourish. The title "Medicare + Choice"-pronounced 
"Medicare plus choice"--was an arithmetic formula any second-grader could grasp: something plus something equals more. The plus sign followed by the word "choice" implied that traditional Medicare did not include any choice and that the new program (as any seven-year old could tell) gave you more. In fact, traditional Medicare includes greater choice among doctors and hospitals than managed care plans.

The rhetoric of consumer choice disguises how much the institutional structure of the new program constrains individual choice after the initial choice of a managed care plan. Most of the managed care plans restrict their beneficiaries to a small network of doctors and hospitals under contract with the insurer, in contrast to the standard Medicare, where consumers have complete freedom to use almost any doctor and hospital in the country. Some managed care plans allow members to use providers outside the plan's network, but charge them extra if they do. Charging people for free choice hardly counts as an expansion of choice compared to traditional Medicare, and for low-income beneficiaries, the higher charge effectively eliminates their choice. In traditional Medicare, patients do not need a referral from a primary care doctor in order to consult a specialist, while in most managed care plans they do-another diminution of choice. Under Medicare + Choice, beneficiaries are allowed to switch their plan only once a year, during a specified open enrollment period. "Free choice" thus becomes a choice with long duration-painfully long for patients who find that their plans refuse to authorize doctors, referrals, tests and treatments that they would like to chose. Such a long-term commitment might be experienced as a trap rather than an opportunity. In all these ways, Medicare + Choice is intended and designed to restrict individuals' choices of providers, and in turn, to restrict providers' ability to supply services. It is, in short, designed to govern.

\section{The Limits of Consumer Choice as Governing Technology}

As in the Danish case, there are good reasons to think that free choice of insurance plans for Medicare beneficiaries was in large part a strategy for empowering and enriching the private sector. In the U.S., private insurers' main competitive strategy has always been cream-skimming - selecting healthy people as policy holders, refusing to insure sick and potentially high medical care users, and denying claims and dumping policy holders once they begin to incur high costs (Stone 1993). Given this well-known behavior, the promise that competition would drive commercial insurers to deliver better services for less money was somewhat disingenuous, if not delusional. Indeed, legislators, lobbyists and other politicians who planned Medicare's managed competition included prohibitions on riskselection and cream-skimming, but the prohibitions were only half-hearted.

In the 1982 TEFRA law, an HMO was required to "accept beneficiaries in the order in which they apply up to the limits of its capacity ...." So far, so good, but then came the loophole as a big as a barn door: ". . . unless to do so would lead to . . . an enrolled population unrepresentative of the population served by the HMO" (Congressional Research Service 1997: 51). HMOs could use the "unrepresentative" excuse to reject people, and who would know? By 1997, insurers' risk selection had been highly publicized and labeled as "discrimination." Several states were making laws and regulations to prohibit these practices. Not surprisingly, the Balanced Budget Act included more specific non-discrimination requirements than TEFRA, but it included the same giant loophole. Insurance plans were forbidden to deny enrollment on the basis of physical and mental illnesses, medical history, past use of medical care, insurance claims experience, genetic testing information, or disability. However, "these provisions do not apply if they will result in enrollment substantially misrepresentative of the Medicare population in the service area" (Congressional Research Service 1997: 55). Plans were also forbidden to "disenroll" members on account of their health status or medical care use, but nothing prohibited 
them from driving members to opt out by refusing to pay their claims or grant them referrals. That such prohibitions were included in the law shows that legislators knew the practices were occurring. For all the black ink, however, the escape-hatch phrase "unrepresentative of the population" and the difficulty of policing enrollment and disenrollment meant that the rules against cream-skimming were bound to be ineffectual.

Although managed care plans were technically prohibited from rejecting applicants on account of their health status, they still benefited from positive risk selection. They tended to draw healthier and younger beneficiaries who didn't need much medical care, and they could and did market to this healthier segment. In plans sponsored by doctors, doctors could steer their healthier patients to join while counseling their sicker patients to stay in traditional medical care (Congressional Budget Office, 1997: 31). Hence, private insurers could use "passive cream-skimming" to enhance profit without making much effort to provide quality care at lower cost.

Even before the Medicare + Choice provisions went into effect, several studies had estimated that because of favorable risk selection, Medicare was paying at least 5 percent more for its enrollees in managed care plans than it would have paid had they remained in traditional fee-for-service Medicare (Congressional Budget Office 1997: 29; Weissman et al. 2005: 482). With this knowledge in hand, legislators included in the Balanced Budget Act a provision for adjusting payment according to the health status of plan members ("health based risk adjustment"). Predictably, however, the managed care industry was able to delay its implementation for several years. When plans realized the government was serious about using risk adjustment to help Medicare save money, they lobbied hard against any risk adjustment, and many withdrew from Medicare and/or eliminated the extra benefits they had used to induce beneficiaries to join (Weissman et al. 2005: 488-91).

Medicare's payment formulas also dilute the disciplinary power of managed competition. Similar to the Danish payment system, Medicare's capitation payments often include increments for things besides medical care that traditional Medicare subsidizesespecially medical education, charity care, and care of low-income beneficiaries (Congressional Research Service 1997: 52). Many managed care plans don't provide these "extras," so the payment formulas give them bonuses that they don't need to earn by being efficient. In order to attract managed care plans to unprofitable rural areas, Congress set the managed care rates in rural areas higher than rates for treating traditional Medicare patients (Congressional Budget Office 1997: 29). Here, too, managed care companies had no incentive to be more efficient. Again in 2003, the Medicare Modernization Act set advantageous rates for managed care plans, so that by 2006 , Medicare was paying 12 percent more to private plans than it cost to cover people in traditional Medicare.

In 2003, during debates over the new drug benefit, the pharmaceutical industry forced legislators to prohibit Medicare from negotiating prices with drug companies (Oberlander, 2013). This provision undermined the neoliberal raison d'etre for free markets. It guaranteed that government would not save money through competitive bidding - the purported rationale for using private drug insurers in the first place.

Consumer choice could perhaps be an effective governing technology, but a second-face interpretation of U.S. health policy would be as incomplete as a simple firstface interpretation. We have to ask ourselves, "Who governs whom?" As Jonathan Oberlander notes, by the mid-1990s when Medicare reform was up for debate, managed care had taken off in the private sector. By 1995, well over 150 million Americans were enrolled in some form of managed care (Oberlander 2003b: 114). Numerous, wellcapitalized managed care plans were now a powerful constituency for opening Medicare's coffers to the private sector, and a powerful lobby for ensuring that any new program rules would be favorable to them. In the face of insurers' ability to organize as trade 
associations, garner major contributions to legislators' election campaigns, and influence the drafting of laws and regulations, neoliberalism's ideal type of market competition dissolves into a very different kind of struggle.

\section{Two Faces, Two Countries and Five Lessons}

Our comparison of similar neoliberal health care reforms in two vastly different political systems demonstrates quite clearly how the integration between the two faces makes it possible to expand both private markets and governing at the same time. In both countries, the political impetus for free choice reform came not from consumers, citizens, patients, doctors, grassroots or social movements, but rather from political elites. These elites presented free choice as benefiting all citizens because choice enlarged their "rights" or "freedom," and because free choice would make the health care system work better to everyone's benefit. It is perhaps not unusual for policies to be elite dominated, but noting this top-down origin sets the stage for our depiction of free choice rhetoric and reforms as governing technologies.

Lesson \#1: Policymakers use neoliberal reforms to make a sector more governable, not necessarily to fulfill ideological goals in one direction or another.

In both countries, policymakers intentionally attached the free choice reforms to widely recognized problems in each public sector and framed free choice as the solution. Yet, even though the reforms were essentially the same - giving welfare state beneficiaries a choice between public and private providers at the taxpayers' expense the policy goals were almost diametrically opposite. In Denmark, the problem was defined as an undersupply of specialist and non-acute hospital care generating unacceptable waiting times for treatment in public hospitals. The powerful image of the 'lethal waiting list' served to increase public support for using private hospitals to expand the supply of health services even though Danish voters were not willing to let go of their public system. By giving patients access to free choice when their home hospital could not deliver, the government was able to push public hospitals to produce more while at the same time giving commercial opportunities to the emerging private sector. In the United States, the problem was defined as unacceptable cost growth caused by excessive use of health services, some of it provider-induced. Policy makers therefore sought to contract the supply of health services, by giving patients free choice among the traditional fee-forservice Medicare and private managed care plans.

The governing mechanism thus works in roughly the same way across countries, but with different objectives. Although one country tried to expand production and the other to reduce it, the ambition of both policies was to be able to control the supply of health services. Here is the crux of the second face: neoliberal reforms do not simply try to govern the health care system in a specific direction, but more fundamentally, they seek to make it governable.

Lesson \#2: Neoliberal reforms may sometimes be used to expand or have an expansive effect on the provision of publicly financed services.

The two cases demonstrate another reason why we think the standard interpretation of neoliberal reforms as state decline must be supplemented by attention to the second face. In both countries, neoliberal technologies of governing were used to expand the supply of health care services by combining public and private production of services financed by the central government. In Denmark, the reforms aimed to increase the supply of services available to citizens in the public sector, in part by funding the 
private sector and allowing it to compete with public hospitals. In the U.S., the reforms aimed to induce private insurers to share the risk of insuring elders.

Thus, neoliberal reforms, in addition to expanding the governability of a sector, may also alter the scope of publicly financed services, either by expanding the range of providers as in the Danish case or by limiting the range of choices as under managed care in the US. Perhaps inadvertently, but almost inevitably, when government channels money into the private sector to provide publicly funded services, it stimulates the private sector to seek a greater share of this new market comprised of publicly financed customers. Such growth might be seen as good if the government's goal was expanding services, as in Denmark, or bad if the government's goal was curbing its expenditures, as in the U.S.

Lesson \#3: Neoliberalism doesn't mean less government; it means governing through homo oeconomicus instead of homo democraticus.

Policymakers in both countries aimed to restructure health policy through a reconfiguration of incentives facing providers and patients. As we have argued, following Foucault, the design of incentives is a neoliberal way for government to make actors respond in a desired fashion given what costs and payoffs they see before them. Both reforms strengthened consumer decision-making (if only partially) in order to put pressure on health care providers.

According to neoliberal theory, consumer choice initiates a chain reaction of beneficial behavioral responses and can thus be used to influence other actors besides consumers. In theory and in political rhetoric, the virtuous circle always starts with consumers (patients in our health care cases). The system is "consumer driven." Viewing these reforms through the second face, however, the consumer also appears as the endpoint of the cycle, the governed rather than the governor. In practice, much of consumers' behavior (as well as other actors' behavior, such as insurers, hospitals and doctors) has already been determined, or at least shaped, by the rules and incentives designed into government policies. For example, in Denmark, the bold claims about free choice and "letting the money follow the patient" stand in contrast to how few patients actually get to choose. Since the free choice is conditional upon waiting time and since the policy is designed to eliminate waiting time, the window for free choice gets smaller the better the policy instrument works. In Medicare, once patients enroll in managed care, they have many fewer choices about providers and treatments, and thus no clout vis-a-vis their insurers or their providers. They are at the mercy of insurers' coverage decisions. The only way free choice can work as a disciplinary tool is if managed care plans must increase the quality and quantity of care that patients receive in order to attract enrollees and be profitable. But in practice, the plans don't have to attract existing members, because their exit options are limited once enrolled in a plan. Thus, in both free choice reforms, patients lost or would eventually lose much of the promised freedom to make autonomous choices.

As our case studies suggest, with any neoliberal policy reform, citizens as consumers may gain some entry and exit options into markets. But they may lose voice to the extent that private businesses do not provide channels for consumer participation and influence (Hirschman 1970). To broaden the point, neoliberal market reforms may strengthen the citizen as a consumer of government services, but not as a participant in deliberative and electoral democratic policymaking (Brown 2003).

Lesson \#4: Neoliberal policies do not create efficient private markets, but take their efficiency for granted. Nonetheless, neoliberalism purports to create mechanisms to make the public sector efficient. 
Scholars of neoliberalism have tended to emphasize either the goal of increasing free markets and private enterprise, or the goal of governing individual and organizational behavior. Our study illuminates how the two goals can sometimes work against each other. In both countries, concessions and policy rules meant to strengthen the private sector actually weakened or undermined the effectiveness of consumer choice as a disciplinary tool.

In both cases, payment formulas were often so lucrative that private insurers and providers had no need to be efficient in order to make a profit. The Danish free choice reform opened the gates for large amounts of public revenue to flow into private hospitals but without significant pressure on them to be efficient. When there are no restrictions on specialization, and no obligations for teaching and providing acute care, and when private hospitals are systematically overpaid, the job of being the public sector's watchdog can be very profitable without doing much watching. In the U.S., in order to attract private insurers to participate in insuring the elderly, policymakers legislated payment formulas that often paid managed care plans more than the cost of providing care to beneficiaries in the traditional fee-for-service plan.

Neoliberal policymakers, by simply assuming that private business is more efficient than government, may design policies that eliminate the imperative to be efficient. In so doing, they undermine the mechanism and rationale for privatization as a disciplinary tool.

\section{Lesson \#5: The two faces of neoliberalism are inextricably intertwined.}

Standard scholarship on neoliberalism tends to see the private market and government as players in a zero-sum game. As we have tried to show, the two work much more in unison than this image suggests. The integration becomes apparent once we focus on the use of incentives and markets to govern behavior. Political elites use imagery of consumers and free choice as a political appeal to open up the public sector to private providers so that they can discipline each other. To the extent that private providers get access to a public stream of revenue, this process can be interpreted along the lines of the first face of neoliberalism stressing how government "cedes territory" to the private sector. However, the state also gains some leverage over the private sector by allowing it access to public sector clientele and revenue only on condition that business adheres to certain rules set by the state.

Thus, the power of neoliberalism lies not in the replacement of the activist state with a minimalist night watchman state, but rather, in how it can use the public and private sectors to keep each other in check, so to speak. Critical to our argument, ceding territory to the private sector doesn't necessarily come at the expense of government power. Instead of thinking of neoliberalism as shifting a territorial boundary, we suggest thinking of it as making the boundary between public and private more porous. Understood from a second-face perspective, neoliberalism can work as a tool for disciplining and even expanding the public sector, and as a tool for the state to discipline the private sector and expand its participation in fulfilling public responsibilities.

This is not to say that the relationship between the public and private sectors is always an equal contest. But the point is precisely not to see neoliberalism as a zero-sum game. Under neoliberalism, private and public are not like territories, but parts of an integrated political mechanism for making actors use their 'free choice' in socially constructive ways. 


\section{REFERENCES}

Bachrach, Peter and Morton S. Baratz, "Two Faces of Power," American Political Science Review, vol. 56, no. 4: 947-52.

Becker, Gary (1976). The Economic Approach to Human Behavior. Chicago: The University of Chicago Press.

Blumenthal, David and James A. Morone (2009). The Heart of Power: Health and Politics in the Oval Office. Berkeley: University of California Press.

Blyth, Mark (2002). Great Transformations: Economic Ideas and Institutional Change in Twentieth Century. New York: Cambridge University Press.

Braithwaite, John (2008). Regulatory Capitalism: How It Works, Ideas for Making It Better. Cheltenham: Edward Elgar.

Brown, Lawrence D. and Lawrence R. Jacobs (2008). The Private Abuse of the Public Interest: Market Myths and Policy Models. Chicago: University of Chicago Press.

Brown, Wendy (2003). "Neo-liberalism and the End of Liberal Democracy", Theory \& Event vol. 7 , no. 1, pp. 1-18.

Buchanan, James M. (1986). Liberty, Market, and State. Political Economy in the 1980s. Brighton: Wheatsheaf.

Cahill, Damien (2011). "Neoliberalism: Crisis and Prospects for Progressive Alternatives," New Political Science vol. 33, no. 4, pp. 479-492.

Campbell, John L. and Ove K. Pedersen (eds) (2001). The Rise of Neoliberalism and Institutional Analysis. Princeton: Princeton University Press.

Congressionial Budget Office (1997, December). "Budgetary Implications of the Balanced Budget Act of 1997. Washington, D.C.

Congressional Research Service (1997). "Medicare Provisions in the Balanced Budget Act of 1997 (BBA 97, P.L. 105-33). Washington, D.C. Report 97-802.

Enthoven, Alain C. (1980). Health Plan: The Only Practical Solution to the Soaring Cost of Medical Care. Reading, Mass.: Addison-Wesley.

Enthoven, Alain C. and Richard Kronick (1989a). "A Consumer Choice Health Plan or the 1990s: Universal Health Insurance in a System Designed to Promote Quality and Economy, Part I." New England Journal of Medicine vol. 320, pp. 29-37.

Enthoven, Alain C. and Richard Kronick (1989b). "A Consumer Choice Health Plan or the 1990s: Universal Health Insurance in a System Designed to Promote Quality and Economy, Part II." New England Journal of Medicine vol. 320, pp. 94-101.

Enthoven, Alain C. and Richard Kronick (1991). "Universal Health Insurance Through Incentives Reform." Journal of the American Medical Association, vol. 265, no. 19, May 15, pp. 2532-36.

Foucault, Michel (2008). The Birth of Biopolitics. Lectures at the Collège de France 19781979. London: Palgrave. 
Friedman, Milton (1962). Capitalism and Freedom. Chicago: University of Chicago Press.

Frank, Thomas (2000). One Market Under God: Extreme Capitalism, Market Populism, and the End of Economic Democracy. New York: Random House.

Gilder, George (1984). The Spirit of Enterprise. New York: Simon and Shuster.

Greenfield, Kent (2012): The Myth of Choice: Personal Responsibility in a World of Limits (New Haven: Yale University Press).

Hackey, Robert (2012). Cries of Crisis: Rethinking the Health Care Debate. Reno, Nevada: University of Nevada Press.

Hardis, Arne (2006). "Hjortens flugt" (interview with Minister of Employment Claus Hjort Frederiksen), Weekendavisen, August 18.

Hardis, Arne and Hans Mortensen (2003). "Interview" (with Prime Minister Anders Fogh Rasmussen), Weekendavisen, January 17.

Harvey, David (2005). A Brief History of Neoliberalism. Oxford: Oxford University Press.

Hayek, Friedrich A. (1960). The Constitution of Liberty. Chicago: The University of Chicago Press.

Hirschman, Albert O. (1970). Exit, Voice, and Loyalty. Responses to Decline in Firms, Organizations, and States. Cambridge: Harvard University Press.

Jensen, Carsten (2011). "Marketization via Compensation: Health Care and the Politics of the Right in Advanced Industrialized Nations," British Journal of Political Science, vol. 41, no. 4, pp. 907-26.

Jessop, Bob (2002). "Liberalism, Neoliberalism, and Urban Governance:A StateTheoretical Perspective", Antipode 34, pp. 452-72.

Jost, Timothy Stoltzfus (2007). Health Care at Risk: A Critique of the Consumer-Driven Movement. Durham: Duke University Press.

Jørgensen, Heine and Peter Korsgaard (2011). "Bertel om ventetider: Folk vælger det selv", Ekstra Bladet September 22011.

Klein, Naomi (2007). The Shock Doctrine: The Rise of Disaster Capitalism. (New York, Henry Holt).

Kastrup, Mads (2008). "Den borgerlige kulturkamp" (interview with Prime Minister Anders Fogh Rasmussen), Berlingske Tidende, June 15.

Kohn, Alfie (1983). Punished By Rewards. Boston: Houghton Mifflin.

Law L64 (2002). Forslag til lov om ændring af lov om sygehusvæsenet. Copenhagen: Folketinget.

Levi-Faur, David (2005). "The Global Diffusion of Regulatory Capitalism," Annals of the American Academy of Political Science vol. 598, pp. 12-32. 
Mikkelsen, Palle and Jens Erik Streenstrup (1988). Brugerbetaling: Prioritering - styring fordeling. Copenhagen: AKF.

Ministry of Health and Domestic Affairs (2007). Sundhedssektoren i tal. Copenhagen: Ministry of Health and Domestic Affairs.

Mueller, Dennis C. (2003). Public Choice III. Cambridge: Cambridge University Press.

Niskanen, William A. (1971). Bureaucracy and Representative Government. New Brunswick: AldineTransaction.

Nozick, Robert (1974). Anarchy, State and Utopia. Cambridge, Mass.: Harvard University Press.

Oberlander, Jonathan (2003a). The Political Life of Medicare. Chicago: University of Chicago Press.

Oberlander, Jonathan (2003b). "The Politics of Medicare Reform," Washington and Lee Law Review vol. 60, no ?, pp. 1095-1136.

Oberlander, Jonathan (2013 forthcoming). "Medicare: The Great Transformation." In Health Care Politics and Policy, $5^{\text {th }}$ ed. Eds. James A. Morone and Daniel Ehlke. New York: Delmar/Cengage Learning.

OECD (2011). OECD Health Data 2011. Available at www.oecd.org/health/healthdata

Olesen, Jeppe Dørup (2009). "Policymaking without Policy Choice: The Rise of Private Health Insurance in Denmark," Journal of Public Policy, vol. 29, no. 3, pp. 263-85.

Olesen, Jeppe Dørup (2010). Adapting the Welfare State. Privatisation in Health Care in Denmark, England and Sweden. PhD-thesis, European University Institute, Florence.

Pallesen, Thomas (1997). Health Care Reforms in Britain and Denmark: The Politics of Economic Success and Failure. Aarhus: Politica.

Pallesen, Thomas and Lars Dahl Pedersen (2008). "Health Care in Denmark: Adapting to Cost Containment in the 1980s and Expenditure Expansion in the 1990s", pp. 227-50 in Albæk, Erik, Leslie C. Eliason, Asbjørn Sonne Nørgaard and Hermann M. Schwartz (eds), Crisis, Miracles, and Beyond. Negotiated Adaptation of the Danish Welfare State. Aarhus: Aarhus University Press.

Panitch, Leo and Martijn Konings, (2009). "Myths of Neoliberal Deregulation," New Left Review vol. 57, May/June, pp. 67-83.

Petersen, Jørn Henrik (1980). "Kan man - som alternativ til central planlægning - benytte elementer af markedsmekanismen i den offentlige sektor?", Nordisk administrativt tidsskrift 4, 61: 29-44.

Petersen, Niels and Helle Blomquist (1996). Sundhed. Byrokrati. Politik. Copenhagen: Jurist- og Økonomforbundets Forlag.

Politiken (1991). "Det private sygdomsmarked vokser", Politiken April 41991. Quadagno, Jill (2007). One Nation Uninsured: Why the U.S. Has No National Health Insurance. New York: Oxford University Press. 
Rand, Ayn (1957). Atlas Shrugged. New York: Random House.

Rasmussen, Anders Fogh (1993). Fra socialstat til minimalstat. En liberal strategi. Copenhagen: Samleren.

Rasmussen, Anders Fogh (2002). New year's speech, January $1^{\text {st }}$. Copenhagen: Prime Minister's Office.

Rhodes, R.A.W. (1994). "The Hollowing Out of the State: The Changing Nature of the Public Service in Britain", The Political Quarterly 65(2), pp. 138-51.

Rigsrevisionen (2009). Beretning til Statsrevisorerne om pris, kvalitet og adgang til behandling på private sygehuse. Copenhagen: Rigsrevisionen.

Schultze, Charles L. (1977). The Public Use of the Private Interest. Washington, D.C.:

Brookings Institution Press.

Skinner, B.F. (1971). Beyond Freedom and Dignity. New York: Knopf.

Stone, Deborah (1993). "The Struggle for the Soul of Health Insurance." Journal of Health Politics, Policy and Law, vol. 18, no. 2, p.p. 287-317.

Stone, Deborah (2012, $3^{\text {rd }}$ ed). Policy Paradox: The Art of Political Decision Making. New York: W.W. Norton.

Thaler, Richard H. and Cass R. Sunstein (2009 rev. ed.). Nudge: Improving Decisions About Health, Wealth, and Happiness. New York: Penguin.

Thiemann, Per (2007). "Privathospitaler myldrer frem”, Nyhedsavisen May 242007.

Vrangbæk, Karsten (2004). Ingeniørarbejde, hundeslagsmål eller hovedløs høne? Ventetidsgaranti til sygehusbehandling. Aarhus: Magtudredningen.

Wacquant, Loïc (2009). Punishing the Poor: The Neoliberal Government of Social Insecurity. Durham: Duke University Press.

Weissman, Joel S., Wachterman, Melissa, Blumenthal, David (2005). "When Methods Meet Politics: How Risk Adjustment Became Part of Medicare Managed Care." Journal of Health Politics Policy and Law vol. 30, no. 3, pp. 475-504.

White, Joseph. 2001. False Alarm: Why the Greatest Threat to Social Security and Medicare is the Campaign to "Save" Them. Baltimore: Johns Hopkins University Press. 